\title{
An Institutional Approach to Developing a Culture of Student Persistence
}

Gary J Burkholder ${ }^{\mathrm{a},}{ }^{*}$, Jim Lenio ${ }^{\mathrm{b}}$, Nicole Holland ${ }^{\mathrm{b}}$, Alan Seidman ${ }^{\mathrm{b}}$, Diane Neal ${ }^{\mathrm{b}}$, Jimmy Middlebrook ${ }^{b}$, and Rebecca Jobe ${ }^{c}$

a The National Hispanic University, United States

${ }^{\mathrm{b}}$ Walden University, United States

${ }^{\mathrm{c}}$ Laureate Online Education, United States

Submitted: May 19, 2013 | Peer-reviewed: June 30, 2013 | Editor-reviewed: July 5, 2013

Accepted: July 18, 2013 | Published: September 30, 2013

Abstract: There continues to be increasing focus on college student retention and persistence. This focus is coming from the United States federal government, accrediting organizations, and from students, parents, and the public. Given the spiraling costs of education and the fact that retention rates have not improved over time, various stakeholders are concerned about the value of a higher education credential. The purpose of this manuscript is to describe the efforts of a for-profit, distance education institution to focus its resources, in an evidence-based manner, on retention and to develop a culture of retention and persistence throughout the institution. The literature review and analysis of internal initiatives demonstrated that (a) institutions must make a commitment to retention, include retention efforts as part of its strategic plan, and provide resources to support retention efforts; (b) mastery of knowledge of the research on retention and persistence is critical for designing evidencebased interventions; and (c) institutions should identify, develop, and implement pilot projects aimed at improving student progress and share results to help stimulate development of best practices throughout higher education.

Keywords: Retention, institutional approaches, retention theories, student persistence, institutional retention strategy

\section{Introduction}

College student retention continues to be a concern for all degree levels and for all types of institutions of higher education, including community colleges, public four year colleges and universities, and private colleges and universities

* Corresponding author (gary.burkholder@nhu.edu)

Suggested citation: Burkholder, G, J., Lenio, J., Holland, N., Seidman. A., Neal, D., Middlebrook, J., Jobe, R. (2013). An institutional approach to developing a culture of student persistence. Higher Learning Research Communications, 3(3), 16-39. http://dx.doi.org/10.18870/hlrc.v3i3.120 
(Seidman, 2005; 2012). Data for the four-year undergraduate college sector from the American College Testing show that retention figures have remained relatively unchanged over time (American College Testing [ACT], 2010, 2012). At $\mathrm{PhD}$ granting public institutions, freshman to sophomore retention rate was $78.6 \%$ in 2010 and $76.7 \%$ in 2012 . Retention at $\mathrm{PhD}$ granting private institutions was higher; freshman to sophomore retention rates in 1985 was $85 \%$ and in 2012, it was at $80.2 \%$ (ACT, 2010). Results suggesting stability or even decline are similar for graduation rates. At public $\mathrm{PhD}$ granting institutions, the best 5-year graduation rate was 50.6 in the 1989-1990 years; in 2012, the rate was $48 \%$ (ACT, 2012). At PhD private institutions, the highest graduation rate was $68.8 \%$ in 1986; in 2012, it was $62.9 \%$ (ACT, 2012).

In spite of efforts by institutions, retention and graduation rates have not improved over time. Graduation rates are still at about $50 \%$ at the postsecondary level, and about half of all college students withdraw from their initial institution after one year (Swail, 2004). Lovitts (2001) identified several consequences of attrition from doctoral programs. These included costs to departments subject to elimination of academic programs not demonstrating success; costs to the university and society in terms of reduced contribution that non-completing doctoral students bring to society; and to students who bear the "financial, personal, and professional costs of attrition" (p. 6).

There are two primary purposes for this paper. First, it reviews the empirical and theoretical literature related to retention and graduation that serves as the foundation for the Institution's efforts to create a culture of persistence. Second, it provides a detailed description and analysis of the evidence-based, institutional approach to retention. The overall goal is to share what has been found and to continue the dialogue among institutions that can help achieve the collective goal of improved retention and graduation. Given the institutional mission and composition, the focus of this paper will be on persistence among non-traditional (21st century or contemporary) students. 


\section{Higher Education Institutions and Retention Rates}

Federal and state governments are becoming more involved in retention and graduation; much of the focus has stemmed from the increasing lag in United States compared to other countries in college completion and the spiraling costs of education. President Obama noted that the United States ranks 9th in the world in terms of those enrolled in college and that lifetime earnings for college graduates are twice that of those with a high school diploma only (The White House, 2013a, para. 2). In addition, he has made clear his goal of 5 million graduates from community colleges by 2020 (2013a, para. 10). Further, the President has proposed methods of making graduation rates of institutions more transparent to parents and consumers and, at the same time, providing preferences to institutions that contain costs while achieving higher value (The White House, 2012). The overall federal focus, then, appears to be on education quality and retention and graduation rates while improving access through affordability.

Complicating the issue is the focus of discussion on for-profit higher education. For-profit education applies principles of profitability and free market dynamics to the business of providing higher education. Many of these entities have been created to improve access to domestic and/or global education (for example, Laureate Education, Inc., see www.laureate.net; and University of Phoenix, see www.uopx.edu), as well as to improve access to those who have not historically been served by traditional colleges and universities (for example, working adults and first generation college students).

Given the rapid rise of the for-profit higher education sector and low graduation rates across all higher education sectors, there has been increased review of for-profit institutions. For instance, the U.S. Department of Education (2011) noted that "Students at for-profit institutions represent 12 percent of all higher education students, 26 percent of all student loans and 46 percent of all student loan dollars in default" (para. 4). The U.S. Senate Committee on Health, Labor, Education, and Pensions (2012), chaired by Sen. Tom Harkin, reported that,

A 2-year investigation by the Senate Committee on Health, Education, Labor, and Pensions demonstrated that Federal taxpayers are investing billions of dollars a year, $\$ 32$ billion in the most recent year, in companies that operate for-profit colleges. Yet, more than half of the students who enrolled in in [sic] those colleges in 2008-9 left without a degree or diploma within a median of 4 months. (p. 1) 
Clearly, there is increased attention on quality of education as well as the role played by for-profit education sector. One additional example is the gainful employment provision for for-profit education; the provision limits the types of programs eligible for Title IV federal financial aid disbursement (Department of Education, 2011, para. 3).

The Committee also noted the importance of for-profit education by stating,

The existing capacity of nonprofit and public higher education is insufficient to satisfy the growing demand for higher education, particularly in an era of drastic cutbacks in State funding for higher education. Meanwhile, there has been an enormous growth in nontraditional students-those who either delayed college, attend part-time or work full-time while enrolled, are independent of their parents, or have dependents other than a spouse. This trend has created a "new American majority" of non-traditional students. (U.S. Senate Committee on Health, Labor, Education, and Pensions, 2012, p. 1)

In the report, it was noted that problems related to retention included not providing adequate student services during and post-education. Inadequate services are viewed as a key reason for increasing student debt and failure to attain the credentials sought (that is, low retention and graduation rates).

There are benefits to the institution for higher graduation and retention rates. In an era of increased scrutiny and accountability, meeting the President's objectives for cost, value, and quality of higher education, increased graduation and retention rates would be one measure of success. In fact, President Obama has suggested allocating federal financial aid award money to institutions that can demonstrate that they are achieving those objectives (The White House, 2013b). For all institutions, retaining students means a predictable and steady revenue stream that maximizes financial performance (Seidman, 2012). For state and private schools having not-for-profit status, this can translate into growth of their financial foundations that, among other things, serve students through scholarships and grants. In for-profit education, this leads to investor confidence and financial growth of the company. Improved graduation and retention rates can serve also as an embedded marketing advantage, since students will want to attend schools that can demonstrate success at good value (this also could theoretically lead to lower marketing costs relative to overall institution costs). 
The concern regarding low retention and graduation rates in general appears legitimate from multiple perspectives. The United States Department of Education wants to be certain that the money it spends is providing a return that advances national interests and the economy. Institutions have an incentive to provide quality education at a reasonable cost. Students (and parents and the public at large) have increasing questions about the return for a significant investment in a post-high school credential. Given that retention and graduation are priorities for all institutions, sharing of best practices among them is important.

\section{Context of the Higher Education Institution}

This paper presents the case of a for-profit, distance education institution having regional accreditation in the United States. Its mission is to serve career professionals using a social change framework at the core of the educational model and mission. Current enrollment is approximately 50,000 students. These students are earning degrees at the bachelor, masters, specialist, and doctoral degree levels. The institution also offers various certificate programs for those seeking specialized training. Programs are offered in 4 primary disciplines (Social and Behavioral Sciences; Health Sciences; Education and Leadership; and Management and Technology). Several of the programs have professional accreditation, including Commission on Collegiate Nursing Education (CCNE; http://www.aacn.nche.edu/ccne-accreditation); the Council for Accreditation of Counseling and Related Education Programs (CACREP; www.cacrep.org); Accreditation Council* for Business Schools and Programs (ACBSP; www.acbsp.org); National Council for Accreditation of Teacher Education (NCATE; www.ncate.org); among others.

Given the mission to serve primarily career professionals, a sizeable majority of the students are adult (or non-traditional) learners. While it is challenging to identify the non- traditional learner (also called the 21st Century or contemporary learner; Advisory Committee on Student Financial Assistance [ACSFA], 2012), our students at the graduate and undergraduate levels tend to reflect contemporary definitions; these include definitions based on age, current and previous employment status, minority status, and generation of college student, among others (ACSFA, 2012). Institutional statistics indicate that about $83 \%$ of students are in graduate programs (masters, specialist, and doctoral); $74.8 \%$ are women; $46.8 \%$ of the enrollments are students who report minority race/ethnicity; $54.4 \%$ report one or more children living at home; $76 \%$ report working full time, with $71 \%$ of those currently working in the profession represented by the academic program. Average age is 39 years, and about $18 \%$ are first generation college students. 


\section{Review of the Literature}

The review of the literature includes two parts. It first briefly summarizes some of the key theoretical approaches to retention with a particular focus on their utility with non- traditional students (for a more thorough historical treatment of the evolution of retention models, see the comprehensive review by Berger, Ramirez, and Lyons (2012); our review focuses mainly on models developed since the 1980's that began to consider non- traditional students). For the purposes of this research, nontraditional students are defined as those who fall into several distinct categories (the challenges of nontraditional students are described during discussion of the institutional approach to retention). Nontraditional students include: (a) older students who don't fit the same age profile as the typical first time freshman; (b) those who have significant responsibilities outside of their academic program that compete for time and resources, including part-time or full-time employment and family responsibilities; (c) those students who attended college at one time but, for whatever reasons, dropped out and are returning after a significant time away from higher education; and (d) first generation college students, those who are the first in their family to attend (and potentially graduate from) college. Salter (2012) provided a detailed and excellent exploration of retention issues related to online students; the focus of this paper will be on the institutional approach to retention. In the second part of the review, it includes an analysis of the key findings from the empirical literature related to persistence for nontraditional students attending distance education programs.

\section{Theoretical Approaches to Retention}

Astin. Astin (1984) drew upon a number of psychological learning theories, such as psychoanalysis and classical learning, in formulating the theory of student involvement, one of the early comprehensive models of persistence. Generally, students who are more involved with the various aspects of their educational experience will be more likely to persist. He counteracted traditional student learning theories that treated students as a black box into which is directed policies regarding how students are supposed to learn and out of which emerges measured. In his view, current models at the time did not provide insight into how students were learning.

The theory posited a combination of personal and environmental factors that determined student involvement and hence persistence (Astin, 1984). Personal factors included academic and family background as well as student aspirations. Environmental factors included residence, employment, and college 
characteristics. The importance of environmental factors, for example, was supported by his empirical research that showed that living in dormitories or being members of sororities and fraternities had a positive impact on persistence. Faculty student interaction was important; those who had more positive interactions were likely to express overall greater satisfaction with the institution. The goal of the theory was to shift what was previously favored - the academically prepared and assertive student - to the one who is underprepared and less assertive.

Astin focused the theory of student involvement in the college life of traditional students. His theory did not account for nontraditional students who began to move into higher education in larger numbers beginning in the late 20th century.

Bean and Metzner. Bean and Metzner (1985) and Bean (2005) developed the theory of persistence that focused on non-traditional students. Bean and Metzner posited that external factors more than institutional involvement factors impact nontraditional students. This reflects the fact that nontraditional students tend to not be as involved in the campus (they do not live there) and have demands, such as employment and family responsibilities, different from traditional age students.

The Bean and Metzner model posited 4 key domains important for persistence. The first domain included background variables such as high school performance, educational goals, and demographic factors. The second domain included variables directly related to academic performance, such as study habits and use of academic advising. The third domain described intention to leave; background, academic performance, and psychological variables significantly impact student intention to leave. The fourth and final domain included environmental factors including finances, hours worked, and family responsibilities. Metzner and Bean (1987) found that variables in the last domain (environmental) were more important to persistence than social integration factors among non-traditional students. They believed that strong support in environmental factors for nontraditional students can compensate for weaker academic preparation.

Tinto. Tinto (1993) expanded meaning of student involvement. He took a sociological and interactionist approach to persistence; academic and social integration were necessary in order to maximize persistence. Tinto posited that initial student commitment and early institutional commitment to graduate students primarily influence college student departure. He also suggested that student academic and social integration into the formal and informal academic and social systems of the institution impact retention. In his model, he later 
shifted the issue of persistence from characteristics of the student to persistence as an institutional problem (Tinto, 2012). A student comes to an institution with specific background (family) characteristics as well as various levels of preparation and aspirations for completing college. Retention is based on how the student is integrated into the formal academic structures (academic work as well as scheduled activities such as clubs) and informal academic structures (activities that foster student interaction outside of the classroom).

Much research has generally supported Tinto's theory of academic and social integration. The research has generally shown that academic integration factors are far more important than social integration factors in determining whether a student will stay or leave an institution. However, research also has demonstrated ethnicity an important factor in academic and social integration. Of note is that Tinto developed his original model to explain the experience of the traditional college student experience (that is, those right out of high school). Many researchers have attempted to expand his theory to explain the experiences of other types of students (for example, minority and older students) (Berger \& Braxton, 1998; Braxton, Sullivan, \& Johnson, 1997; Longwell-Grice \& Longwell-Grice, 2007; Metz, 2005; Nora, 2002). For example, Latino students, because of their deeper connection to their own communities, tend to find their college experiences close to home; this reflects the importance of social integration into the academic world (Saenz, Hurtado, Barrera, Wolf, \& Yeung, 2007).

Lovitts. There are no standards for measuring graduate level retention, and there is very little research available to this area. Attrition for the first year of graduate school accounts for almost a third of all doctoral attrition (Golde, 1998). Furthermore, $50 \%$ of all doctoral students do not complete their degrees (Dorn \& Papalewis, 1997). Initial results of the Council of Graduate Schools Ph.D. Completion project (Bell, 2007) suggested a 57\% 8-year Ph.D. completion rate.

Most of the research has focused on retention and graduation at the undergraduate level. Lovitts (2001) noted doctoral attrition as "the invisible problem" (p. 1). She noted as well that attrition cannot be explained as a problem with admissions standards; students admitted to traditional doctoral programs tend to be those who are the highest academic achievers and are at the outset the most likely to succeed. Lovitts identified several factors related to doctoral student persistence that are a combination of both academic and social integration factors (p. 257). These included (a) institutional level factors, including selectivity and demands for student commitment to studies; (b) disciplinary level, 
related to norms within the discipline for training graduate students; (c) departmental, including opportunities for academic and social integration as well as methods for advisor selection; and (d) individual level factors, including the degree of academic and social integration, quality of interactions with advisor, external factors, and degree intentions.

Seidman. Seidman (2012) conceptualized an inclusive model describing persistence for all types of students, including traditional and non-traditional, minority, and those who attend brick and mortar and virtual universities. Model factors included early identification of challenges and early, intensive, and continuous intervention to address the challenges / deficits. The institution first needed to identify foundational skills necessary for student success; students should acquire these skills during participation in early college courses, and skill development become part of the student's program of study. Such skills might include the textual reading, critical thinking, writing, and mathematics. The institution assesses students for potential deficits early and then they are provided with the skills needed for success in a first university course.

Seidman (2012) suggested delivering needed skills in a non-traditional, modularized format. Students engaged in these modules across multiple modalities (on ground or online). Success in the modularized courses is required for continued registration. Such approaches to skill development overcome a common complaint that students already know the material and see such courses as not contributing to their requirements for graduation, as many of these courses carry no credit (Silverman \& Seidman, 2012).

\section{Analysis of the Approaches}

In spite of research and theorizing that has taken place for nearly more than 50 years, rates of persistence remain not only relatively low but also have remained relatively stable (ACT, 2012); this is true as well for distance education institutions that tend to attract nontraditional learner. In fact, these institutions may be at a disadvantage; nontraditional students, for a number of reasons identified in several lines of research and analysis (for example, ACSFA (2012)), may be less likely at the outset to be successful. Analysis of the current educational landscape and the theoretical guidance suggested the following: (a) the costs of education is significant and needs to be contained (The White House, 2012); (b) More students of non-traditional age are attending school (many for the first time) and comprise a higher proportion of those going to school (ACSFA, 2012); (c) many of the factors of non-traditional students do not 
favor retention, including first generation status, age, and the need to balance multiple and simultaneous family, work, and educational realities (ACSFA, 2012); and (d) traditional factors used to guide admissions, such as grade point average, are likely not as important a predictor of success as the extent to which institutions recognize the importance of environmental factors (Metzner \& Bean, 1987). Thus, models of persistence for these students need to focus more on environmental and institutional factors that intersect and can have enormous impact on student engagement and retention. Also needed is a clearer understanding about motivation of nontraditional students to remain in school and to continue to juggle the competing demands of work, family, and school.

\section{Results of Empirical Studies on Retention with Non-traditional Distance Education Students}

Student retention. Boston and Ice (2011) found that, among nontraditional undergraduate students, the top 5 predictors of failure to retain (explaining $38.5 \%$ of the variance) included, in the order of their importance: (a) having no transfer credits $(15.8 \%$ of the variance); (b) registering for more courses in a year (4.5\% of the variance); (c) the last grade being an $\mathrm{F}(3.8 \%$ of the variance); (d) last grade received as a W (withdraw) (2.7\% of the variance); and (e) GPA of 4.0 (1.4\% of the variance). Harrell and Bower (2011) found, in a sample of undergraduate community college students, that grade point average, auditory learning style, and basic computer skills - reflecting individual characteristics - best predict successful completion of online courses. In an unpublished study (Walden University, 2010), overall, students admitted in a conditional status (those who did not meet regular admissions criteria) by an admissions committee retained better at one year than those who were regularly admitted $(77.7 \%$ compared with $65.9 \%$, respectively). This evidence suggests that entry grade point average is not necessarily a good predictor of success for non-traditional students. Park and Choi (2009) did not find any differences in individual characteristics, such as age, gender and educational background, on those who persisted in an online learning experience. Sutton and Nora (20082009) found that student intent to persist and perceived institutional commitment contributed to persistence.

Researchers have found varying results related to integration factors. Riedel and Lenio (2010) found that graduate student perceptions of closeness with the institution did not predict retention. Boston et al. (2009) found that social presence (operationalized as student and teacher engagement in the classroom) explained $21.1 \%$ of the variance in course completion. Finnegan, Morris, and 
Lee (2009) found, in an analysis of undergraduate students in an online course, that number of discussion postings read, number of original posts, number of follow-on posts, and time spent reading discussions and content areas of the course were significant predictors of final course grade. They also found differences in course engagement factors between social science students and students in science, technology, engineering, and math (STEM) majors (for example, successful social sciences students were much more likely to view discussion postings). Kember (1999) found that students who found support from family, friends, and coworkers, made sacrifices to achieve goals, and were successful in negotiating competing demands were able to successfully integrate family, work and social lives. The research of Park and Choi (2009) supported this finding. They found in a sample of adult learners that those who persisted were more likely to report family and organizational support.

A number of researchers have examined the importance of orientation programs for online student success. Lenio et al. (2009) found that, when controlling for other factors associated with retention, participation in a face-toface residency was statistically associated with one-year retention. Ali and Leeds (2009) found that a face-to-face orientation resulted in improvement in retention, compared to a control, of $91 \%$ versus $18 \%$, respectively.

Institutional strategies. There is a paucity of published research on institutional approaches to retention integrated as part of an overall institutional strategy. McCracken (2008-2009) conducted an extensive review of the theoretical literature on persistence for students enrolled in online courses and noted several important considerations, including (a) the importance of a coordinated approach to learning and support; this includes comprehensive information on all aspects of program involvement from admission to graduation; (b) this comprehensive support must be available for new and existing students; and (c) use of a central point for support (for example, the website or a student portal). Morris and Finnegan (2008-2009) suggested a number of strategies, including (a) using tools to track student task frequency and time; (b) providing meaningful feedback to students; (c) establishing course norms using data collected over time to identify student work needed to demonstrate success; and (d) ensuring faculty are clear on course requirements and using faculty as technological liaisons if students encounter issues. Faculty should actively manage the online experience for students by engaging in discussions and asking meaningful and thought-provoking questions.

Colleges have spent vast sums of money to help students succeed (Silverman \& Seidman, 2011-2012). This includes enhanced student academic 
and personal counseling, early alert/warning systems and student assessment of academic skills prior to enrollment. Over time, institutions have strengthened remedial programs and services as well as developed special support services for minorities and low income students. Even with these interventions, retention figures at the baccalaureate level have not improved over time. However, without these programs and services, retention figures potentially would have plummeted.

\section{Outlining Retention Initiatives}

Review of the literature suggested a number of themes upon which we based our retention initiatives. These included: (a) faculty engagement - faculty involvement in the classroom is a factor in retention; (b) comprehensive support - students who persist are more likely to perceive adequate levels of support; and (c) attention to environmental factors - those students who are able to negotiate the demands of work, family, and education are more likely to report being successful. What also emerged from the review is that there is still very incomplete understanding of the factors related to persistence at the undergraduate level, particularly for non-traditional, distance education students. In addition, research on graduate persistence is even more sparse and incomplete. Institutions such as ours are poised to add significantly to understanding persistence and the role that individual, institutional, academic, and social factors play in retention.

\section{University Institutional Approach to Retention}

\section{Retention Research and Reporting (Prior to 2011)}

Many individuals across the institution have focused on improving retention and the overall student experience. This presentation details two distinct phases of research: Before and after 2011. Initial efforts on retention included gathering data to support quarterly retention rate reporting and short term projects that measured the success of individual institutional retention efforts. Some of these initiatives are described below, and Table 1 provides more information about the key retention-related initiatives undertaken prior to 2011.

Quarterly academic retention and graduation rate reports. In 2007, the first institutional report was produced. The purpose was to assemble retention and graduation related information and report it quarterly to key stakeholders. This report included, among other information, waterfall-type reports that showed cohort retention term-to-term, which showed how students in a given cohort persisted by term over the duration of the program. These 
also provided graduation rates by cohort. These reports were important for providing quantitative information to programs as part of the regular review process. It also allowed the institution to begin to benchmark against other institutions (recognizing the difficulty of establishing true comparison schools).

Retention studies for master's programs in psychology and public health programs. In 2005 and 2006 (respectively), the institution worked with academic leaders in these two programs to conduct a deep analysis of retention trends and predictors (these were the predecessors to the contemporary and more formalized academic program reviews). What was unique about these studies at that time is that they examined data available from regarding students at the pre-enrollment, enrollment, and the withdrawal stages. Significant attrition was found during the first two terms before leveling off at the third term forward. As a result, the researchers of this paper engaged in a deep analysis of the first term student experience; from these results, they significantly revised the foundations (first-term) courses, and leaders from both programs involved in the study examined more closely first term faculty engagement and quality. Unfortunately, they did not run rigorous tests to verify effectiveness.

Master's and doctoral level research classroom experiences. The master's thesis and doctoral dissertation were strengthened by creating required classroom experiences for students in this phase of their academic experience. Analysis at the one-year point indicated that students in doctoral and master's level research classrooms had a statistically significantly smaller time to completion than those who had not been previously enrolled in the required experience (Burkholder, Jobe, Smeaton, \& Lenio, 2008). As a result, all students in capstone classes at the master's and doctoral level were moved into mandatory classrooms.

Table 1. Retention Initiatives, Key Finding, and Presentation of Findings (Prior to 2011)

\begin{tabular}{|l|l|l|l|}
\hline Year & \multicolumn{1}{|c|}{ Initiative } & \multicolumn{1}{c|}{ Finding } & \multicolumn{1}{c|}{ Results } \\
\hline $2006-$ & $\begin{array}{l}\text { School of Psychology } \\
\text { and Public Health } \\
\text { Program Retention } \\
\text { Studies. }\end{array}$ & $\begin{array}{l}\text { - Retention significantly } \\
\text { decreases first two terms } \\
\text { and levels off after term } \\
\text { three. }\end{array}$ & $\begin{array}{l}\text { - Investment in a } \\
\text { comprehensive first course } \\
\text { experience. }\end{array}$ \\
$\begin{array}{l}\text { - Students who reserve } \\
\text { earlier are more at risk for } \\
\text { dropping out. }\end{array}$ & $\begin{array}{l}\text { - Creation of the Student } \\
\text { Readiness Orientation to } \\
\text { engage students while they } \\
\text { wait for courses to start. }\end{array}$ \\
\hline
\end{tabular}




\begin{tabular}{|c|c|c|c|}
\hline 2007 & $\begin{array}{l}\text { Thesis and Dissertation } \\
\text { Students in Psychology } \\
\text { placed in required } \\
\text { classrooms. }\end{array}$ & $\begin{array}{l}\text { - Time to completion } \\
\text { decreases (statistically } \\
\text { significant compared to } \\
\text { students not in classrooms). }\end{array}$ & $\begin{array}{l}\text { - All students in thesis and } \\
\text { dissertation placed in } \\
\text { classrooms. } \\
\text { - Research support products } \\
\text { (resources, examples) } \\
\text { enhanced in classrooms. } \\
\text { - Presented at the } 2008 \\
\text { Annual Convention of the } \\
\text { American Psychological } \\
\text { Association, Division 2, } \\
\text { Teaching of Psychology. }\end{array}$ \\
\hline 2008 & $\begin{array}{l}\text { Relationship between } \\
\text { face-to-face doctoral } \\
\text { residencies and one year } \\
\text { retention. }\end{array}$ & $\begin{array}{l}\text { - Students who took their first } \\
\text { residency within } 90 \text { days of } \\
\text { completing the first course } \\
\text { retained at a statistically } \\
\text { higher rate than those who } \\
\text { did not. }\end{array}$ & $\begin{array}{l}\text { - Students were encouraged } \\
\text { at enrollment and by } \\
\text { program leadership in their } \\
\text { first courses to register early } \\
\text { for the first residency } \\
\text { experience. } \\
\text { - Presented at the } 2009 \\
\text { Association for Institutional } \\
\text { Research Annual Meeting. }\end{array}$ \\
\hline 2010 & $\begin{array}{l}\text { Community predictors of } \\
\text { retention. }\end{array}$ & $\begin{array}{l}\text { - Social support outside the } \\
\text { classroom predicted } \\
\text { retention. } \\
\text { - Feelings of community did } \\
\text { not predict retention. }\end{array}$ & $\begin{array}{l}\text { Presented at the } 2010 \\
\text { Association for Institutional } \\
\text { Research Meeting. }\end{array}$ \\
\hline 2010 & $\begin{array}{l}\text { Conditional Admissions } \\
\text { Analysis. }\end{array}$ & $\begin{array}{l}\text { Students who were } \\
\text { admitted conditionally (did } \\
\text { not meet university grade } \\
\text { point average requirements) } \\
\text { retained at a statistically } \\
\text { higher rate than those who } \\
\text { were admitted via regular } \\
\text { admission. }\end{array}$ & $\begin{array}{l}\text { - Evidence used to justify } \\
\text { continuing the conditional } \\
\text { admission policy and use of } \\
\text { Admissions Committees to } \\
\text { make decisions regarding } \\
\text { students who do not meet } \\
\text { regular admissions } \\
\text { requirements. }\end{array}$ \\
\hline
\end{tabular}


Although the institution had engaged in a number of retention initiatives, the research on retention had generally lacked a clear structure or agenda. Various departments continued to commission projects on an ad-hoc basis; funding occurred only to the extent projects were planned in advance and included in annual budget negotiations. Two events occurred in 2011 that caused a shift of focus of retention to the institutional level; these were the creation of the University Retention Team and the Office of Student Progress Initiatives.

\section{The University Retention Team}

The University Retention Team consisted of members of the Office of Institutional Research and Assessment, and a number of additional members who brought specific expertise in quantitative and qualitative analysis methodology, historical knowledge of the institution, and graduate and undergraduate retention best practices. The committee began work on a two year, four phase retention research initiative. The primary aim of this initiative was to identify specific actions that have a high likelihood of increasing student retention. Initially, the team undertook an extensive review of the literature to understand better the recent research on retention related to online, nontraditional students.

Phase I: Retention profiles development. In this phase, variables for inclusion into 6-month and one-year retention models were identified. Researchers identified variables based on a careful review of the literature and that will be included in logistic regression models. Data supporting the four phases of this retention initiative originate from two main sources: the annual student satisfaction surveys and from the student information system. Standalone databases were created from student information system data that are used to track student retention in a given program or degree level term-overterm; these are used to report retention metrics through the institutional dashboard. Using these data files as the starting point, researchers can match relevant survey and student information systems data to retention records based on student identification number. To create models of retention for cohorts of students at different points in time in more sophisticated ways, current and historical student satisfaction survey data were merged. 
Phase II: Survival models. This phase employed the statistical technique of survival analysis to show conditional probabilities of retention over multiple terms and allowed for analysis beyond a single point in time. Survival models also allowed for deeper analysis into bachelor and doctoral programs which have longer times to degree as the models will continue past six months and one year. This will help to better understand the specific predictors of persistence in time rather than at fixed end points.

Phase III: Retention mechanisms. This phase involveed conducting specific, in- depth analyses to identify the casual mechanisms behind specific factors affecting retention to understand why they did or did not have an impact. Essentially, this phase examined the underlying assumptions and beliefs of why certain retention strategies were used. The examination resulted in the ability to specifically identify why a strategy was or was not successful.

Phase IV: Intervention testing. This phase looked retrospectively to examine the success or failure of retention interventions. Intervention testing is ongoing and described in more detail below.

The University Retention Team has the responsibility for analyzing and interpreting the findings of the data to the larger institution; these data also inform specific interventions. The stages do not happen in linear sequence; for example, Phase IV activities are operating concurrently with Phase I activities. However, it is expected to use the results of the analysis at all phases to influence the development of pilot projects focused on various retention initiatives. There also is an institutional commitment to present findings at national conferences and publish the findings for the use of institutions with similar student populations.

\section{Office of Student Progress Initiatives}

The second event involved the creation of a new position dedicated to driving student progress and an overall improved student experience: The Executive Director, Student Progress Initiatives (EDSPI). The role of the executive director is to focus the efforts of the office on testing and implementing best practices in persistence and retention. The charge of the office was to create a systematic approach to studying factors related to student progress and developing, executing, and assessing the impact of a strategic plan put into place to better the student experience and students' progress towards their educational goals. The executive director is a member of the University 
Retention Team and partners closely with the Vice President of Student Experience (VPSS) among other stakeholders. The EDSPI and VPSS coordinated the strategic plan for retention initiatives in a series of steps.

Step 1: Developing the methodological approach. The methodological approach established the foundation for testing new initiatives, analyzing the impact, and making data-driven decisions based on the results of pilot testing new initiatives.

Step 2: Establishing a collaborative, cross-functional summit. The summit was used to bring together academic and business leaders from across the organization to review internal and external data and discuss the various perspectives on barriers to student progress, gaps in the student experience, and potential ways to reduce those barriers and fill those gaps through institutional policy and process changes. The primary outcome of the summit was a strategic plan with an actionable set of initiatives that would be fully developed, implemented, and tested over the next 16 months.

Step 3: Executing the strategic plan. Following the identification of a set of prioritized initiatives, small core teams were established around each pilot to develop and implement the projects of the initiative. The EDSPI stayed directly involved with all core teams to ensure a) coordination among the initiatives such that effects could be isolated, b) creation of a centralized knowledge base including work on more than 20 initiatives and from 70 individuals involved in the strategic plan, c) constant communication of status and findings across all levels of the organization, and d) socialization of the strategic plan towards the effort of investment in the approach and institutional cultural change. Initiatives launched throughout the cycle at different points in time, depending on the complexity of implementation and other factors related to the programs used for testing.

Step 4: Assessing the outcomes and continuing the cycle. A key feature to this systematic approach was the broad, deliberate communication plan established to keep all key stakeholders informed throughout the process. The executive director provided weekly updates to team members and to the executive and academic leaders, as well as at college-level meetings, semiannual faculty meetings, and other ad-hoc discussions related to student progress and retention.

The EDSPI identified over twenty projects based on discussions among stakeholders across the institution, analysis of the literature on retention, and review of the results of internal retention studies. A sample of these pilot projects 
are: (a) video previews of the next course in the program - these are designed to help students see how the current course fits into the context of their learning and connect that to the subsequent course in the program; (b) faculty-led colloquium series for students designed to build community by engaging with other students and faculty in their programs, expose them early to research and career paths within their field, socializing them to their profession, and set expectations for success; (c) create faculty video clips to put into courses to create a sense of connection between faculty members and students and to relay information about expectations for the course; (d) having books automatically provided as a way to minimize additional burden to students; (e) welcome kits designed to generate a sense of identity with the institution and prepare students for the start of their programs; (f) designing a comprehensive faculty training program specifically focused on the new student/first term experience; and g) designing a peer-tutoring program to better support students in courses that historically create a "barrier" to persistence. Note that a more detailed discussion of the larger student progress strategic plan and the individual initiatives (including results) are currently under development.

\section{Discussion}

In the current economic and political climate, the value of a college education is at stake. Key to the discussions involving education and its value are (a) cost and affordability, (b) value proposition, and (c) ultimate achievement of educational goals. Retention and graduation are fundamental to the ongoing conversation and influence the perceived value and reputation of an institution and the degrees it confers.

Students come with a number of personal factors that predispose them to various levels of engagement in their academic pursuits. Some of these are under the control of the student, such as intention to graduate and commitment to success. Others, such as gender, age, ethnicity, and socioeconomic status, are not. What was clear from the review of the literature is that the institution must make a primary commitment to student persistence. For the purposes of this research, a major demonstration of this commitment happened when an office was identified to oversee retention initiative planning, implementation, monitoring, analysis, and dissemination. At the institution, the University Research Team draws upon experts within the organization to analyze and interpret data, and the Office of Student Progress Initiatives ensures that retention-based pilot studies are implemented and tested and that student progress is a fundamental part of the annual institutional strategic planning conversations. 


\section{Implications for Future Research}

Based on our analysis and our own efforts at creating a culture of persistence at the institution, there are a number of areas requiring further research.

What should be the basis for calculating student retention and graduation rates? The formulas used in the Integrated Postsecondary Education Data System (IPEDS) are the primary ones used to calculate retention rates. However, current formulas are extremely limited and exclude a large number of student populations. For example, retention formulas exclude part-time, transfer, and returning, as well as those students who leave after the second year of enrollment. Therefore, reported retention figures are likely to be inflated. Retention rates will not be generalizable to the entire student body until a new formula is developed that encompasses all types of students (Hagedorn, Moon, Cypers, Maxwell, \& Lester, 2006). Therefore, institutions should begin to explore and report on alternative definitions of retention that include different denominators. It might be, for example, that institutions calculate and share definitions based on first time full time freshmen, first generation students, and/or all students regardless of status. Also, it would be useful to track where students go after leaving the institution. It may be that students leave and move onto another institution; this would represent a success rather than a loss.

There is need for more empirical analyses of predictors of retention and graduation for institutions of all types that serve non-traditional students using a variety of modalities for delivery (face-to-face, blended, and $100 \%$ distance delivery, for example). These predictors should examine not only the impact of individual factors, but also find ways to explore the extent to which academic and social integration factors as well as institutional factors that contribute to persistence. It may be useful to examine afresh the kinds of questions students are asked in end of course evaluations and annual student satisfaction surveys.

While much is known about short term retention, less is known about the predictors of graduation or persistence in the quantitative sense. Survival analysis models can help to better understand the predictors at various times in a student's lifecycle. This can be helpful to understanding the ways institutions can address the needs of students at all stages of their academic careers and not just in the first term or first year.

There is also a need to better understand how institutions are responding to questions about retention and graduation and the specific 
student persistence initiatives that show evidence of success. Reporting the results of initiatives would be useful for cross-organizational sharing of best practices. This can help put limited resources where they can be most effective. More analyses that present institutional approaches to retention are also needed, such as that by Britto and Rush (2013), who presented their institution's approach to comprehensive student support services for online students. The analysis in this paper contributes to that much-needed dialogue.

\section{Conclusion}

The article documents some key theoretical approaches to retention; researchers such as Astin, Tinto, and Lovetts, among many others, have been attempting to better understand the factors related to student persistence. At this time, more than any other, retention, persistence, and graduation have captured the focus of politicians, academicians, students, and the public; there seems to be new questions about the cost and value of post-secondary education. As noted, there are several important questions that remain to be answered, questions that cannot be addressed by the experiences of only a few institutions. Rather, there is an opportunity for institutions, including for-profit and not-for profit, traditional and distance education, to collectively take ownership of the retention and graduation question by analyzing and sharing important data. The article presents one institution's roadmap with the hope that other institutions will continue to share best practices that result in improved retention and graduation rates.

\section{References}

Advisory Committee on Student Financial Assistance (ACSFA) (2012). Pathways to success: Integrating learning with life and work to increase national college completion (Report to the U.S. Congress and the Secretary of Education). Retrieved from http://www2.ed.gov

Ali, R., \& Leeds, E. M. (2009). The impact of face-to-face orientation on online retention: A pilot study. Online Journal of Distance Learning Administration, 12(4). Retrieved from http://www.westga.edu

American College Testing. (2010). National collegiate retention and persistence to degree rates [Policy paper]. Retrieved from http://www.act.org/

American College Testing. (2012). National collegiate retention and persistence to degree rates [Policy paper]. Retrieved from http://www.act.org/ 
Astin, A. W. (1984). Student involvement: A developmental theory for higher education. Journal of College Student Development, 25, 297-308.

Bean, J. P. (2005). Nine themes of college student retention. In A. Seidman (Ed.), College student retention: Formula for student success (pp. 215-244). Westport, CT: ACE/Praeger.

Bean, J. P., \& Metzner, B. S. (1985). A conceptual model of nontraditional undergraduate student attrition. Review of Educational Research, 55(4), 485-540. http://dx.doi.org/10.3102/00346543055004485

Bell, N. E. (2008). Graduate enrollment and degrees: 1997-2007. Washington, D.C.: Council of Graduate Schools.

Berger, J. B., \& Braxton, J. M. (1998). Revising Tinto's interactionist theory of student departure through theory elaboration: Examining the role of organizational attributes in the persistence process. Research in Higher Education, 39(2), 103-119. http://dx.doi.org/10.1023/A:1018760513769

Berger, J. B., Ramirez, G. B., \& Lyons, S. (2012). Past to present: A historical look at retention. In A. Seidman (Ed.), College student retention: Formula for success (2nd. ed., pp. 734). Lanham, MD: Rowman \& Littlefield.

Boston, W., \& Ice, P. (2011). Assessing retention in online learning: An administrative perspective. Online Journal of Distance Learning Administration, 14(2). Retrieved from http://www.westga.edu/

Boston, W., Ice, P., Diaz, S. R., Richardson, J., Gibson, A. M., \& Swan, K. (2009). An exploration of the relationship between indicators of the community of inquiry framework and retention in online programs. Journal of Asynchronous Learning Networks, 13(3), 67-83.

Braxton, J. M., Shaw Sullivan, A. V., \& Johnson, R. M. (1997). Appraising Tinto's theory of college student departure. In J. C. Smart (Ed.), Higher education: A handbook of theory and research (Vol. 12, pp. 107-164). New York, NY: Agathon Press.

Britto, M., \& Rush, S. (2013). Developing and implementing comprehensive student support services for online students. Journal of Asynchronous Learning Networks, 17(1), 29-42.

Burkholder, G. J., Smeaton, G., Jobe, R., \& Lenio, J. (2008, August). Facilitating student completion of independent research: Strategies for success. Symposium session presented at the 116th Annual Convention of the American Psychological Association, Boston, MA.

Department of Education. (2011, June 2). Obama administration announces new steps to protect students from ineffective career college programs [Press release]. Retrieved from http://www.ed.gov/ 
Dorn, S. M., \& Papalewis, R. (1997, March). Improving doctoral student retention. Paper presented at the American Educational Research Association Annual Meeting: Talking Together in Educational Research \& Practice, Chicago, IL.

Finnegan, C., Morris, L. V., \& Lee, K. (2009). Differences by course discipline on student behavior, persistence, and achievement in online courses of undergraduate general education. Journal of College Student Retention: Research, Theory, \& Practice, 10(1), 39-54. http://dx.doi.org/10.2190/CS.10.1.d

Golde, C.M. (1998). Beginning graduate school: Explaining first-year doctoral attrition. New Directions for Higher Education, 101, 55-64. http://dx.doi.org/10.1002/he.10105

Hagedorn, L. S., Moon, H. S., Cypers, S., Maxwell, W. E., \& Lester, J. (2006). Transfer between community colleges and four-year colleges: The all American game. Community College Journal of Research and Practice, 30(3), 223-242. http://dx.doi.org/10.1080/10668920500322384

Harrell, I. L., \& Bower, B. L. (2011). Student characteristics that predict persistence in community college online courses. American Journal of Distance Education, 25(3), 178191. http://dx.doi.org/10.1080/08923647.2011.590107

Kember, D. (1999). Integrating part-time study with family, work and social obligations. Studies in Higher Education, 24(1), 109-124. http://dx.doi.org/10.1080/03075079912331380178

Lenio, J., Holland, N., Cantu, C., Fink, N., Francis, S., \& Baur, D. (2009, June 3). Examining the effect of academic residencies on the retention of online PhD students. Paper presented at the 49th Association of Institutional Research Annual Forum: World Class Institutional Research, Atlanta, GA.

Longwell-Grice, R., \& Longwell-Grice, H. (2008). Testing Tinto: How do retention theories work for first- generation, working-class students? Journal of College Student Retention: Research, Theory \& Practice, 9(4), 407-420. http://dx.doi.org/10.2190/CS.9.4.a

Lovitts, B. E. (2001). Leaving the ivory tower: The causes and consequences of departure from doctoral study. New York, NY: Rowman \& Littlefield.

McCracken, M. (2009). Best practices in supporting persistence in distance education student through integrated web-based systems. Journal of College Student Retention: Research, Theory, and Practice, 10(1), 65-91. http://dx.doi.org/10.2190/CS.10.1.f

Metz, G. W. (2005). Challenge and changes to Tinto's persistence theory: A historical review. Journal of College Student Retention: Research, Theory \& Practice, 6(2), 191-207. http://dx.doi.org/10.2190/M2CC-R7Y1-WY2Q-UPK5

Metzner, B., \& Bean, J. (1987). The estimation of a conceptual model of nontraditional undergraduate student attrition. Research in Higher Education 27(1), 15-38. http://dx.doi.org/10.1007/BF00992303 
Morris, L. V., \& Finnegan, C. L. (2009). Best practices in predicting and encouraging student persistence and achievement online. Journal of College Student Retention: Research, Theory, and Practice, 10(1), 55-64. http://dx.doi.org/10.2190/CS.10.1.e

Nora, A. (2002). The depiction of significant others in Tinto's "Rites of Passage": A reconceptualization of the influence of family and community in the persistence process. Journal of College Student: Research, Theory \& Practice, 3(1), 41-56. http://dx.doi.org/10.2190/BYT5-9F05-7F6M-5YCM

Park, J. H., \& Choi, H. J. (2009). Factors influencing adult learners' decisions to drop out or persist in online learning. Educational Technology and Society, 12(4), 207-217.

Riedel, E., \& Lenio, J. (2010, May 29-June 2). Understanding community among online adult learners. Paper presented at the 50th Association for Institutional Research Annual Forum: Charting Our Future in Higher Education, Chicago, IL.

Saenz, V. B., Hurtado, S., Barrera, D., Wolf, D., \& Yeung, F. (2007). First in my family: A profile of first-generation college students at four-year institutions since 1971. Los Angeles, CA: Higher Education Research Institute.

Salter, D. (2012). Online student retention. In A. Seidman (Ed.), College student retention: Formula for student success (pp. 211-227). Westport, CT: ACE/Praeger.

Seidman, A., (ed.) (2005). College student retention: Formula for student success. Westport, CT: ACE/Praeger.

Seidman, A. (ed.) (2012). College student retention: Formula for student success (2nd ed.). New York, NY: ACE/Rowman \& Littlefield.

Silverman, L., \& Seidman, A. (2011-2012). Academic progress in developmental math courses: A comparative study of student retention. Journal of College Student Retention: Research, Theory \& Practice, 13(3), 267-288. http://dx.doi.org/10.2190/CS.13.3.a

Sutton, S., \& Nora, A. (2008-2009). An exploration of college persistence for students enrolled in web-enhanced courses: A multivariate analytic approach. Journal of College Student Retention: Research, Theory, and Practice, 10(1), 21-37. http://dx.doi.org/10.2190/CS.10.1.c

Swail, W.S. (2004, June 21). The art of student retention: A handbook for practitioners and administrators. Paper presented at the Texas Higher Education Coordinating Board 20th Annual Recruitment and Retention Conference, Austin, TX, Education Policy Institute.

Tinto, V. (1975). Dropout from higher education: A theoretical synthesis of recent research. Review of Educational Research, 45(1), 89-125. http://dx.doi.org/10.3102/00346543045001089

Tinto, V. (1993). Leaving college: Rethinking the causes and cures of student attrition (2nd ed.). Chicago, IL: The University of Chicago Press. 
Tinto, V. (2012). Completing college: Rethinking institutional action. Chicago, IL: University of Chicago. http://dx.doi.org/10.7208/chicago/9780226804545.001.0001

The White House. (2012, January 27). President Obama's blueprint for keeping college affordable and within reach for all Americans [Fact sheet]. Retrieved from http://www.whitehouse.gov/

The White House. (2103a). Education: Knowledge and skills for the jobs of the future. Retrieved from http://www.whitehouse.gov/

The White House. (2013b, February 12). The President's plan for a strong middle class and a strong America. Retrieved from http://www.whitehouse.gov/

U.S. Senate Committee on Health, Labor, Education, and Pensions. (2012, July 30). For-profit higher education: The failure to safeguard the federal investment and ensure student success, S. Prt. 112-37, Vol. 1. Retrieved from http://www.help.senate.gov

Walden University (2010). Walden University Admissions Committee Review. Unpublished study. 